\title{
Anthropogenic impacts on aquatic bacteria: a perspective from the tropics
}

\author{
Impactos antropogênicos em bactérias aquáticas: uma perspectiva dos trópicos
}

\section{Michaela Ladeira de Melo ${ }^{1 *}$ (iD) and Hugo Sarmento ${ }^{1}$ (iD)}

${ }^{1}$ Departamento de Hidrobiologia, Universidade Federal de São Carlos UFSCar, Rodovia Washington Luís, s/n, CEP 13565-905, São Carlos, SP, Brasil

*e-mail: michaelaldemelo@gmail.com

Cite as: Melo, M.L. and Sarmento, H. Anthropogenic impacts on aquatic bacteria: a perspective from the tropics. Acta Limnologica Brasiliensia, 2019, vol. 31, e111

Abstract: Bacterioplankton comprises a highly diverse group of microorganisms, which are dominant in aquatic ecosystems, and play a central role in ecosystem functioning and biogeochemical cycles. Due to their high turnover and dispersal rates, as well as high adaptability and plasticity, microbes are likely to respond quickly to environmental changes and perturbations on their ecosystems. In this opinion paper, we reviewed some studies that addressed bacterial community's responses to anthropogenic impacts in their aquatic environments. Inorganic nutrients and organic matter inputs from the catchment areas are likely to increase due to changes in climate and land use. These changes will impact the microbial community composition and metabolism, as well the amount of energy and carbon flowing through aquatic food webs as mostly demonstrated in studies from temperate and boreal systems. However, due to the low number of studies on microbial communities in tropical ecosystems, our understanding of how they will respond to perturbations in this distinct environmental context is still limited. Research in microbial ecology in southern countries is still in its infancy and deserves more attention in the future, since tropical aquatic ecosystems are hotspots of biodiversity, host most of the world freshwater reserves, and play a key role in global biogeochemical cycles.

Keywords: microbial ecology; bacterial community composition; bacterial metabolism; climate change.

Resumo: $\mathrm{O}$ bacterioplâncton compreende um grupo altamente diversificado de microrganismos, que são dominantes nos ecossistemas aquáticos e desempenham um papel central no funcionamento desses ecossistemas e nos ciclos biogeoquímicos. Devido às suas elevadas taxas de dispersão e de mudança na composiçấo, bem como alta adaptabilidade e plasticidade, os microrganismos devem responder rapidamente às mudanças e perturbaçôes ambientais. Neste artigo de opinião, revisamos alguns estudos que abordaram respostas de comunidades bacterianas aos impactos antrópicos em seus ambientes aquáticos. Os nutrientes inorgânicos e a matéria orgânica das áreas de drenagem provavelmente aumentarão devido às mudanças no clima e no uso do solo. Essas mudanças afetarão a composição e o metabolismo das comunidades microbianas, bem como os fluxos de energia e de carbono nos ecossistemas aquáticos, como majoritariamente demonstrado para sistemas temperados e boreais. No entanto, devido ao reduzido número de estudos sobre comunidades microbianas em ecossistemas tropicais, a nossa compreensão de como elas responderão às perturbaçóes neste contexto ambiental distinto ainda é limitada. As pesquisas em ecologia microbiana nos países do hemisfério sul ainda estão em sua infância e merecem mais atenção no futuro, uma vez que os ecossistemas aquáticos tropicais são hotspots de biodiversidade, abrigam a maior parte das reservas de água doce do mundo e desempenham um papel fundamental nos ciclos biogeoquímicos globais.

Palavras-chave: ecologia microbiana; composição da comunidade bacteriana; metabolismo bacteriano; mudanças climáticas. 


\section{Introduction}

According to the Intergovernmental Panel on Climate Change (IPCC), in tropical regions, increasing temperatures and extreme precipitation events are likely to become more frequent and intense. These changes will impact the amount of energy and organic matter flowing and transported by freshwater ecosystems, with consequences for the structure and functioning of these systems, that can ultimately have impacts on global biogeochemical cycles. However, the effects of climate changes in planktonic communities of tropical regions are still largely unknown (Sarmento et al., 2013).

Bacterioplankton comprises a taxonomically, phylogenetically, and metabolically highly diverse group of microorganisms which are dominant in aquatic ecosystems. They are mediators of biogeochemical fluxes, playing pivotal roles in organic matter degradation, nutrients recycling, energy transfer, and $\mathrm{CO}_{2}$ emissions (Azam et al., 1983; Cotner \& Biddanda, 2002). Due to their high turnover and dispersal rates, and high adaptability and plasticity, microbes are very sensitive and respond quickly to environmental changes and perturbations on their ecosystems (Cotner \& Biddanda, 2002), being good models to address how ecosystem functioning and services respond to disturbances in a changing world context.

Because of the low number of studies covering bacterioplankton diversity in tropical ecosystems, our understanding of how they will respond to perturbations in this environmental context is still limited. However, this is needed since tropical zones host $80 \%$ of the world's biodiversity and 15 of the world's 25 biodiversity hotspots (Harding et al., 2014; Myers et al., 2000), but have received least attention compared to boreal and temperate regions. One of the reasons for that is that tropical regions include the poorest countries in the world, and in those countries, access to sequencing facilities is still a challenge and extremely expensive. At the same time, these countries are those that are more threatened concerning biodiversity loss because of deforestation and changes in land use (Barlow et al., 2016), and also those that host most of the world freshwater reserves (Oki \& Kanae, 2006).

The advent of new tools including next generation sequencing and novel modelling approaches have been modifying our view about the diversity of natural microbial communities and their dynamics across a variety of temporal and spatial scales. These advances have allowed us to unravel the processes and mechanisms underlying microbial diversity and distribution in several aquatic ecosystems (Szekely \& Langenheder, 2014; Ruiz-Gonzaléz et al., 2015), and microbial ecology has been progressively integrated to macroecology (Barbéran et al., 2014), e.g. providing some of the most important contributions to recent developments in community ecology (Vellend, 2010; Stegen et al., 2012) described below.

Currently, it is broadly recognized that microbial communities are simultaneously structured by a combination of deterministic and stochastic processes, which vary according to the characteristics of each ecosystem (Stegen et al., 2012). For instance, species sorting concerns to the differential response in deterministic aptitude among species in relation to a complex combination of abiotic environmental variables and biotic interactions (Leibold et al., 2004). In contrast, stochastic processes include random birth-death events. Mass effect consider the movements of immigration and emigration by deterministic or random causes and has recently been suggested to occur often in aquatic environments due to the high dispersion by water flows (Ruíz-Gonzaléz et al., 2015; de Melo et al., 2019). Because speciation happens in an evolutionary time scale, less attention has been focused in the formation of new species in microbial community's assemblage dynamics (Hubbell, 2011; Vellend, 2010).

Given that many aquatic ecosystems are undergoing rapid and deep modifications by climate changes and human mediated activities, there is an increasing interesting in understanding how these changes, individually or in combination, are affecting the diversity and composition of aquatic bacterial communities across aquatic systems worldwide. Currently, most of the available studies regarding the microbial response to anthropogenic impacts have focused on growth such as bacterial abundance, biomass, and metabolism in temperate and boreal environments (Sand-Jensen et al., 2007; Hall et al., 2009; Özen et al., 2013). However, few studies have actually tested the effects of anthropogenic impacts on the structure and diversity of freshwater bacterial communities. Here, we provide some examples of how changes in freshwater ecosystems could affect the structure and activity of aquatic bacterial communities, and discuss some possible scenarios for the understudied tropical regions. 


\section{Impacts on Bacterial Community's Structure}

Subarctic and arctic regions are threatened by increasing permafrost thawing due to climate warming (González-Eguino \& Neumann, 2016). Similarly, storm-affected areas in tropical zones are likely to experience increases in precipitation and increased risk of flooding. In other words, the on-going climate warming is mobilizing terrestrial carbon pools and increasing the allochthonous carbon inputs from the catchment to surface waters worldwide, ultimately affecting ecological processes and the structure of aquatic microbial communities. These changes could be exemplified by the pure and direct effect of addition of soil bacterial taxa, which are currently considered important sources for bacterial communities located downstream in temperate aquatic habitats (Ruiz-Gonzaléz et al., 2015). Additionally, more complex consequences related with changes in water conditions, i.e. transparency, nutrient concentrations, and quality of organic substrate, are likely to filter the establishment and successful of dispersed bacteria.

It was demonstrated for small and shallow ponds (Roiha et al., 2016) that high concentrations of terrestrial dissolved organic matter (DOM), nutrients, and algal exudates favoured high microbial productivity but selected a less diverse microbial community. In contrast, outlets with a lower degree of exposition to terrestrial DOM and poor in nutrients and humic materials had lower bacterial metabolism, but a more diversified community composition. Overall, these results suggest that terrestrial-DOM inputs are likely to favour heterotrophy relative to autotrophy and decrease microbial diversity.

These findings pointed that also the impact of increased inorganic nutrients inputs (i.e. eutrophication) is another aspect to be considered in synergism with climate warming. Eutrophication might be a result of the interplay of complex socioeconomic factors, which include population and economic growth, dramatic changes in land-use, and the increased consume of artificial fertilizers (de Jonge et al., 2002). Because of that, aquatic systems worldwide, especially in developing countries are experiencing increase in eutrophication trends, and cyanobacterial harmful algal blooms (e.g. O'Neil et al., 2012).

Blooms are known to influence the composition of bacterial communities, especially of some specific taxa (Louati et al., 2015; Berry et al., 2017). During a late spring-summer bloom in Funil reservoir (Rio de Janeiro, Brazil), two periods could be distinguished (Guedes et al., 2018). The first period was characterized by higher retention time, low transparency and dominance of Microcystis, which was positively correlated with Bacteroidetes OTUs (particularly Cytophagales), and negatively correlated with several taxa, including the genera Planctomyces, Limnohabitans, and Hyphomicrobium. The second period was characterized by the dominance of Synechococcus and Cylindrospermopsis raciborskii, which coincided with lower retention time and less turbidity, and an increase in the relative abundance of Planctomycetes. Specifically, they observed a strong correlation between Planctomyces and Synechococcus, and positive correlations between C. raciborskii and the genera Gemmatimonas and Roseococcus.

During a monitoring period of six months, cyanobacterial bloom biovolume remained high for a continuous period of four months $\left(>10 \mathrm{~mm}^{3} \mathrm{l}^{-1}\right.$ of all cyanobacteria) in Yanga Lake, a shallow and ephemeral lake located in Australia (Woodhouse et al., 2016). The lake was mainly dominated by Dolichospermum, Microcystis, Aphanocapsa, Geitlerinema, Oscillatoria, and Sphaerospermopsis, and significant changes in bacterial community composition were observed, a dominance of Actinobacteria and Alphaproteobacteria, when cyanobacterial biovolume were low, and by Actinobacteria, Bacteroidetes and Cyanobacteria when cyanobacterial biovolume were elevated. During periods of high cyanobacterial abundance, Betaproteobacteria, Gammaproteobacteria, Planctomycetes and Verrucomicrobia were also present at substantially greater abundance than at other periods (Woodhouse et al., 2016). Both studies highlight that the structure of bacterial communities in freshwaters are threatened by increased eutrophication on nutrient cycling, especially regarding cyanobacterial blooms. However, to the best of our knowledge, no studies have evaluated consequences of warming and nutrient-enrichment combined for the structure of bacterial communities in tropical waters.

Finally, changes in land use seem to have a great impact on factors structuring microbial communities in aquatic environments. Using the gradient polluted of a subtropical river, the river Chaobai in China, Liao et al. (2018) found differential partitioning in microbial biomass, metabolism, and community composition among three areas with different human activities, less-disturbed mountain areas, 

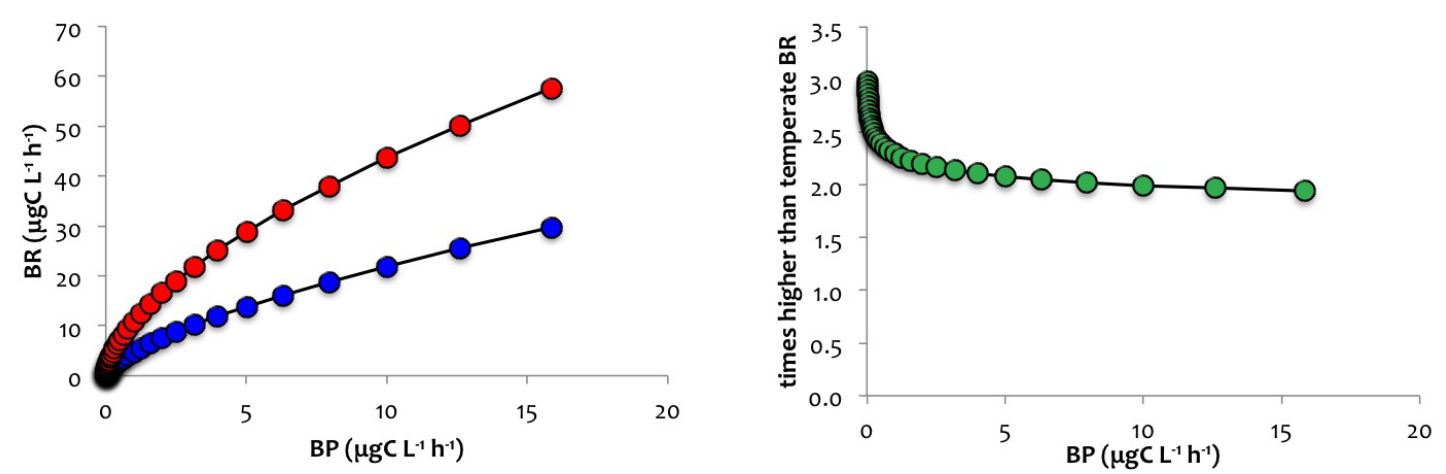

Figure 1. Estimated relationship between bacterial production (BP) and respiration (BR) in temperate (blue) and tropical (red) regions, from a literature review (same database as the one compiled by Amado et al., 2013). The right panel illustrates the tropical:temperate ratio of BR rates (from the left panel): for a given level of BP, BR in tropical regions is expected to be two to three times higher than temperate regions.

urban and agricultural dominated areas. Bacterial communities from mountain areas had significantly higher richness and phylogenetic diversity. In the same study they found that the temperature was the major factor causing variances in sampling seasons, while DOC and chlorophyll- $a$ were critical for the variability among areas. Altogether, these results suggest that a combination of factors related to anthropogenic activities and climate change affect the structure of freshwater bacterial communities.

\section{Bacterial Metabolism}

Besides community composition, microbial metabolism is a subject of big concern regarding anthropogenic impacts on aquatic environments because it directly affects ecosystem services and biogeochemical cycles. Bacterial metabolism (especially bacterial respiration) in warmer regions is expected to be two to three times higher than in temperate regions (Figure 1) (Amado et al., 2013). Therefore, it is likely that increasing water temperatures will have strong impacts on aquatic ecosystems carbon budgets. However, the drivers of bacterial metabolism may act differently according to latitude, as seasonality in the tropics is determined mainly by rainfall rather than temperature (Freitas et al., 2018). Besides, it is likely that temperate systems are more carbon limited, while in tropical systems nutrient limitation is probably more frequent (Amado et al., 2013; Freitas et al., 2018), therefore the effects of anthropogenic impacts might also vary according to geographic region.

One of the few experimental studies that tested the effects of temperature and nutrients input on bacterial metabolism was carried out in tropical humic lagoons, and reported consistent increase in bacterial respiration, decreasing bacterial production, and decreasing bacterial growth efficiency with increasing temperature. However, the effect of nutrient inputs was more idiosyncratic, but seems somehow related to the availability and quality of the dissolved organic carbon in each lagoon (Scofield et al., 2015).

In fact, climate changes will impact inland water differently depending on the region. E.g., considering the huge Brazilian territory, different scenarios could be expected concerning the result of several environmental driving forces in the structure and functioning of aquatic systems (Roland et al., 2012). Although some regions will experience decreased precipitation (increase in the number of consecutive days with no precipitation), other will experience changes in the frequency of precipitation (increase storms in the summer). Therefore, the amount of energy and matter from terrestrial inputs metabolized by microbial communities will be different (Roland et al., 2012).

There is no doubt that the bacterial metabolism in aquatic ecosystems will be impacted by climate changes and anthropogenic interferences, which will certainly affect biogeochemical cycles, since tropical aquatic ecosystems account for a significant share of global greenhouse gas emissions (Aufdenkampe et al., 2011). In this regard, future studies should predict how changes in environmental drivers in different geographic regions will affect the aquatic biota in different scenarios.

\section{Final Remarks and Future Perspectives}

The facilitation of access to sequencing facilities and the development of regional networks of researchers in southern countries may be the key to advance microbial ecology in these regions. 
A good example of how this could be achieved is the $\mu$ SudAqua network (MicroSudAqua, 2019), a group of researchers and students working in microbial aquatic ecology in Latin America, that meet periodically in workshops, seeking to strengthen collaborative research and formation of human resources to promote microbial ecology at the regional level.

In addition to the effects of climate change, anthropogenically-derived water pollution is another major impact within aquatic ecosystems. Until recently the existence of substances as antibiotics, microplastics and chemical pollution in the water environment have received little notice. However, several studies have quantified and described the effect of such pollutants to the structure and functioning of natural microbial communities (see Marti et al., 2014; McCormick et al., 2016; Labbate et al., 2016), which appears to be a hotspot for current and future research in microbial ecology.

\section{References}

AMADO, A.M., MEIRELLES-PEREIRA, F., VIDAL, L.O., SARMENTO, H., SUHETT, A.L., FARJALLA, V.F., COTNER, J.B. and ROLAND, F. Tropical freshwater ecosystems have lower bacterial growth efficiency than temperate ones. Frontiers in Microbiology, 2013, 4, 167. http://dx.doi. org/10.3389/fmicb.2013.00167. PMid:23801986.

AUFDENKAMPE, A.K., MAYORGA, E., RAYMOND, P.A., MELACK, J.M., DONEY, S.C., ALIN, S.R., AALTO, R.E. and YOO, K. Riverine coupling of biogeochemical cycles between land, oceans, and atmosphere. Frontiers in Ecology and the Environment, 2011, 9(1), 53-60. http://dx.doi. org/10.1890/100014.

AZAM, F., FENCHEL, T., FIELD, J.G., GRAY, J.S., MEYER-REIL, L.A. and THINGSTAD, F. The ecological role of water-column microbes in the sea. Marine Ecology Progress Series, 1983, 10(3), 257-263. http://dx.doi.org/10.3354/meps010257.

BARBERÁN, A., RAMIREZ, K.S., LEFF, J.W., BRADFORD, M.A., WALL, D.H. and FIERER, $\mathrm{N}$. Why are some microbes more ubiquitous than others? Predicting the habitat breadth of soil bacteria. Ecology Letters, 2014, 17(7), 794-802. http://dx.doi. org/10.1111/ele.12282. PMid:24751288.

BARLOW, J., LENNOX, G.D., FERREIRA, J., BERENGUER, E., LEES, A.C., NALLY, R.M., THOMSON, J.R., FERRAZ, S.F.B., LOUZADA, J., OLIVEIRA, V.H.F., PARRY, L., RIBEIRO DE CASTRO SOLAR, R., VIEIRA, I.C.G., ARAGÃO, L.E.O.C., BEGOTTI, R.A., BRAGA, R.F., CARDOSO, T.M., JR, R.C.O., SOUZA JUNIOR, C.M., MOURA, N.G., NUNES, S.S., SIQUEIRA,
J.V., PARDINI, R., SILVEIRA, J.M., VAZ-DEMELLO, F.Z., VEIGA, R.C.S., VENTURIERI, A. and GARDNER, T.A. Anthropogenic disturbance in tropical forests can double biodiversity loss from deforestation. Nature, 2016, 535(7610), 144-147. http://dx.doi.org/10.1038/nature18326. PMid:27362236.

BERRY, M.A., DAVIS, T.W., CORY, R.M., DUHAIME, M.B., JOHENGEN, T.H., KLING, G.W., MARINO, J.A., DEN UYL, P.A., GOSSIAUX, D., DICK, G.J. and DENEF, V.J. Cyanobacterial harmful algal blooms are a biological disturbance to Western Lake Erie bacterial communities. Environmental Microbiology, 2017, 19(3), 11491162. http://dx.doi.org/10.1111/1462-2920.13640. PMid:28026093.

COTNER, J.B. and BIDDANDA, B.A. Small players, large role: microbial influence on biogeochemical processes in pelagic aquatic ecosystems. Ecosystems (New York, N.Y.), 2002, 5(2), 105-121. http://dx.doi. org/10.1007/s10021-001-0059-3.

DE JONGE, V.N., ELLIOTT, M. and ORIVE, E. Causes, historical development, effects and future challenges of a common environmental problem: eutrophication. In: E. ORIVE, M. ELLIOTT, V.N. DE JONGE, eds. Nutrients and eutrophication in estuaries and coastal waters. Dordrecht: Springer, 2002, Developments in Hydrobiology, vol. 164. http://dx.doi.org/10.1007/978-94-017-2464-7_1.

DE MELO, M.L., BERTILSSON, S., AMARAL, J.H.F., BARBOSA, P.M., FORSBERG, B. and SARMENTO, H. Flood pulse regulation of bacterioplankton community composition in an Amazonian floodplain lake. Freshwater Biology, 2019, 64(1), 108-120. http://dx.doi.org/10.1111/ fwb. 13198 .

FREITAS, F., VIEIRA, H.H., DE MORAES, G.P., DE MELO, M.L., VIEIRA, A.H. and SARMENTO, H. Productivity and rainfall drive bacterial metabolism in tropical cascading reservoirs. Hydrobiologia, 2018, 809(1), 233-248. http://dx.doi.org/10.1007/s10750017-3472-0.

GONZÁLEZ-EGUINO, M. and NEUMANN, M.B. Significant implications of permafrost thawing for climate change control. Climatic Change, 2016, 136(381), 381-388. http://dx.doi.org/10.1007/ s10584-016-1666-5.

GUEDES, I.A., RACHID, C.T.C.C., RANGEL, L.M., SILVA, L.H.S., BISCH, P.M., AZEVEDO, S.M.F.O. and PACHECO, A.B.F. Close link between harmful cyanobacterial dominance and associated bacterioplankton in a tropical eutrophic reservoir. Frontiers in Microbiology, 2018, 9, 9. http://dx.doi. org/10.3389/fmicb.2018.00424. PMid:29593677.

HALL, E.K., DZIALOWSKI, A.R., STOXEN, S.M. and COTNER, J.B. The effect of temperature on the coupling between phos- phorus and growth in 
lacustrine bacterioplankton communities. Limnology and Oceanography, 2009, 54(3), 880-889. http:// dx.doi.org/10.4319/lo.2009.54.3.0880.

HARDING, S., MCCOMISKIE, R., WOLFF, M., TREWIN, D. and HUNTER, S. State of the tropics 2014 report. Cairns: James Cook University, 2014.

HUBBELL, S.P. The Unified Neutral Theory of BIodiversity and Biogeography (MPB-32). Princeton: University Press, 2011. http://dx.doi. org/10.1515/9781400837526.

LABBATE, M., SEYMOUR, J.F., LAURO, F. and BROWN, M.V. Editorial: anthropogenic impacts on the microbial ecology and function of aquatic environments. Frontiers in Microbiology, 2016, 7, 1044. http://dx.doi.org/10.3389/fmicb.2016.01044. PMid:27458441.

LEIBOLD, M.A., HOLYOAK, M., MOUQUET, N., AMARASEKARE, P., CHASE, J.M., HOOPES, M.F., HOLT, R.D., SHURIN, J.B., LAW, R., TILMAN, D., LOREAU, M. and GONZALEZ, A. The metacommunity concept: a framework for multi-scale community ecology. Ecology Letters, 2004, 7(7), 601-613. http://dx.doi.org/10.1111/j.14610248.2004.00608.x.

LIAO, K., BAI, Y., HUO, Y., JIAN, Z., HU, W., $\mathrm{ZHAO}, \mathrm{C}$. and QU, J. Integrating microbial biomass, composition and function to discern the level of anthropogenic activity in a river ecosystem. Environment International, 2018, 116, 147-155. http://dx.doi.org/10.1016/j.envint.2018.04.003. PMid:29679777.

LOUATI, I., PASCAULT, N., DEBROAS, D., BERNARD, C., HUMBERT, J.F. and LELOUP, J. Structural diversity of bacterial communities associated with bloom-forming freshwater cyanobacteria differs according to the cyanobacterial genus. PLoS One, 2015, 10(11), e0140614. http://dx.doi.org/10.1371/ journal.pone.0140614. PMid:26579722.

MARTI, E., VARIATZA, E. and BALCAZAR, J.L. The role of aquatic ecosystems reservoirs of antibiotic resistance. Trends in Microbiology, 2014, 22(1), 3641. http://dx.doi.org/10.1016/j.tim.2013.11.001. PMid:24289955.

MCCORMICK, A.R., HOELLEIN, T.J., LONDON, M.G., HITTIE, J., SCOTT, J.W. and KELLY, J.J. Microplastic in surface waters of urban rivers: concentration, sources, and associated bacterial assemblages. Ecosphere, 2016, 7(11), e01556. http:// dx.doi.org/10.1002/ecs2.1556.

MICROSUDAQUA. Red Colaborativa en ecologia acuática microbiana de América Latina [online]. USA: MicroSudAqua, 2019 [viewed 7 Oct 2019]. Available from: https://sites.google.com/view/microsudaqua/

MYERS, N., MITTERMEIER, R.A., MITTERMEIER, C.G., DA FONSECA, G.A.B. and KENT, J. Biodiversity hotspots for conservation priorities.
Nature, 2000, 403(6772), 853-858. http://dx.doi. org/10.1038/35002501. PMid:10706275.

O'NEIL, J.M., DAVIS, T.W., BURFORD, M.A. and GOBLER, C.J. The rise of harmful cyanobacteria blooms: The potential roles of eutrophication and climate change. Harmful Algae, 2012, 14, 313-334. http://dx.doi.org/10.1016/j.hal.2011.10.027.

OKI, T. and KANAE, S. Global hydrological cycles and world water resources. Science, 2006, 313(5790), 1068-1072. http://dx.doi.org/10.1126/ science.1128845. PMid:16931749.

ÖZEN, A., ŠORF, M., TROCHINE, C., LIBORIUSSEN, L., BEKLIOGLU, M., SØNDERGAARD, M., LAURIDSEN, T.L., JOHANSSON, L.S. and JEPPESEN, E. Long-term effects of warming and nutrients on microbes and other plank- ton in mesocosms. Freshwater Biology, 2013, 58(3), 483-493. http://dx.doi.org/10.1111/ j.1365-2427.2012.02824.x.

ROIHA, T., PEURA, S., CUSSON, M. and RAUTIO, $\mathrm{M}$. Allochthonous carbon is a major regulator to bacterial growth and community composition in subarctic freshwaters. Scientific Reports, 2016, 6(1), 34456. http://dx.doi.org/10.1038/srep34456. PMid:27686416.

ROLAND, F., HUSZAR, V.L.M., FARJALLA, V.F., ENRICH-PRAST, A., AMADO, A.M. and OMETTO, J.P.H.B. Climate change in Brazil: perspective on the biogeochemistry of inland waters. Brazilian Journal of Biology $=$ Revista Brasileira de Biologia, 2012, 72(3, Suppl), 709-722. http:// dx.doi.org/10.1590/S1519-69842012000400009. PMid:23011300.

RUIZ-GONZALÉZ, C., NINO-GARCIA, J.P. and DEL GIORGIO, P.A. Terrestrial origin of bacterial communities in complex boreal freshwater networks. Ecology Letters, 2015, 18(11), 1198-1206. http:// dx.doi.org/10.1111/ele.12499. PMid:26306742.

SAND-JENSEN, K., PEDERSEN, N.L. and SØNDERGAARD, M. Bacterial metabolism in small temperate streams under contemporary and future climates. Freshwater Biology, 2007, 52(12), 2340-2353. http://dx.doi.org/10.1111/j.13652427.2007.01852.x.

SARMENTO, H., AMADO, A.M. and DESCY, J.-P. Climate change in tropical fresh waters (comment on the paper 'Plankton dynamics under different climatic conditions in space and time' by de Senerpont Domis et al.). Freshwater Biology, 2013, 58(10), 2208-2210. http://dx.doi.org/10.1111/ fwb. 12140 .

SCOFIELD, V., JACQUES, S.M.S., GUIMARÁES, J.R.D. and FARJALLA, V.F. Potential changes in bacterial metabolism associated with increased water temperature and nutrient inputs in tropical humic lagoons. Frontiers in Microbiology, 2015, 6(310), 
310. http://dx.doi.org/10.3389/fmicb.2015.00310. PMid:25926827.

STEGEN, J.C., LIN, X., KONOPKA, A.E. and FREDRICKSON, J.K. Stochastic and deterministic assembly processes in subsurface microbial communities. The ISME Journal, 2012, 6(9), 16531664. http://dx.doi.org/10.1038/ismej.2012.22. PMid:22456445.

SZEKELY, A.J. and LANGENHEDER, S. The importance of species sorting differs between habitat generalists and specialists in bacterial communities. FEMS Microbiology Ecology, 2014, 87(1), 102-112. http://dx.doi.org/10.1111/1574-6941.12195.

PMid:23991811.
VELLEND, M. Conceptual Synthesis in Community Ecology. The Quarterly Review of Biology, 2010, 85(2), 183-206. http://dx.doi.org/10.1086/652373. PMid:20565040.

WOODHOUSE, J.N., KINSELA, A.S., COLLINS, R.N., BOWLING, L.C., HONEYMAN, G.L., HOLLIDAY, J.K. and NEILAN, B.A. Microbial communities reflect temporal changes in cyanobacterial composition in a shallow ephemeral freshwater lake. The ISME Journal, 2016, 10(6), 1337-1351. http://dx.doi. org/10.1038/ismej.2015.218. PMid:26636552.

Received: 14 May 2019 Accepted: 18 October 2019 